\title{
Fibrin Glue Does Not Improve Healing of Gastrointestinal Anastomoses: A Systematic Review
}

\author{
Tyge Nordentoft ${ }^{a} \quad$ Hans-Christian Pommergaard $^{b}$ Jacob Rosenberg ${ }^{b}$ \\ Michael Patrick Achiam ${ }^{c}$ \\ a Department of Gastrointestinal Surgery 360, Hvidovre Hospital, ${ }^{b}$ Department of \\ Gastrointestinal Surgery D, Center for Perioperative Optimization, Herlev Hospital, and \\ 'Department of Gastrointestinal Surgery, Rigshospitalet, University of Copenhagen, \\ Copenhagen, Denmark
}

\section{Key Words}

Anastomoses · Fibrin glue $\cdot$ Fibrin sealant $\cdot$ Healing $\cdot$ Sealing

\begin{abstract}
Background/Aim: Anastomotic leakage remains a frequent and serious complication in gastrointestinal surgery. In order to reduce its incidence, several clinical and experimental studies on anastomotic sealing have been performed. In a number of these studies, the sealing material has been fibrin glue (FG), and the results in individual studies have been varying. The positive effect of anastomotic sealing with FG might be due to the mechanical/physical properties, the increased healing of the anastomoses or both. The aim of this systematic review was to evaluate the existing evidence on the healing effects of FG on gastrointestinal anastomoses. Methods: PubMed, EMBASE and the Cochrane databases were searched for studies evaluating the healing process of gastrointestinal anastomoses after any kind of FG application. The search period was from 1953 to December 2013. Results: Twenty-eight studies were included in the qualitative synthesis. These studies were all experimental studies, since no human studies used histological or biochemical evaluation of healing. In 7 of the 28 studies, a positive effect of FG on healing was found, while 8 studies reported a negative effect and 11 studies found no effect. Furthermore, 2 studies reported unclear results. The difference in the study outcome was independent of the study design and the type of FG used. Conclusion: In the available studies, FG did not consistently have a positive influence on the healing of gastrointestinal anastomoses. It is consequently plausible that the positive effect of FG sealing of gastrointestinal anastomoses, if there is any, may be due to a mechanical sealing effect rather than due to improved healing per se.


Nordentoft et al.: Fibrin Glue Does Not Improve Healing of Gastrointestinal Anastomoses: A Systematic Review

\section{Introduction}

Gastrointestinal anastomosis is a common surgical procedure both in cancer surgery and in the treatment of benign gastrointestinal diseases. Anastomotic leakage is a serious complication after gastrointestinal surgery resulting in a significant increase in the 30-day mortality and morbidity rates. The mortality rate of this complication may be as high as $13-27 \%$ [1-8]. The reported anastomotic leakage rates are 1-39\%, but a comparative evaluation of the studies is difficult due to the lack of standardized definitions [9-11]. In addition to the immediate clinical consequences, anastomotic leakage is an independent predictor of reduced cancer-specific and general survival [11-14]. Leakage may present as generalized peritonitis requiring surgical intervention, as a more localized accumulation of pus (abscess) or as subclinical leakage that may only be recognized radiologically. Subclinical leakages are considered to be less dangerous and have less impact on the outcome [15-17].

Sealing of the anastomosis with a variety of materials has been investigated in both clinical and experimental studies as an attempt to reduce the frequency as well as the consequences of anastomotic leakage. Unfortunately, many of these attempts have failed to show convincing results [18-48]. Numerous studies have reported on the sealing of gastrointestinal anastomoses with fibrin glue (FG), also called fibrin sealant. FG is designed to mimic the final steps of the blood coagulation cascade, forming a stable physiological fibrin clot that assists hemostasis and wound healing. The fibrin clots formed from FG are similar to normal blood clots and are naturally degraded after a few weeks by the body's enzymes. FG is available as a fluid $[49,50]$ or bound to a mesh [51]. In most studies on FG, the commercially produced FG was used, but in some studies FG was produced locally in the clinical setting from human or animal blood. Positive effects of FG on intestinal anastomoses have been found in both human and experimental studies $[47,48]$. However, healing has not been the primary end point in these studies. Therefore, it is unclear if the positive effect has been due to increased mechanical strength, protection of the anastomosis by a sealing effect or better healing per se.

The aim of the present systematic review was to investigate if FG has a histological or biochemical effect on the healing of gastrointestinal anastomoses.

\section{Methods}

This systematic review was conducted and reported according to the PRISMA guidelines [52, 53].

\section{Search Strategy}

The search strategy aimed to identify all human and experimental studies investigating the application of any kind of FG to gastrointestinal anastomoses. A systematic literature search was performed in December 2013 on PubMed (1953-2013; restriction: English language) and EMBASE (1947-2013; unrelated terms; restriction: English language). The following search string was used: (c(c(c(((fibrin adhesive[MeSH Terms]) OR fibrin glue[MeSH Terms]) OR fibrin[MeSH Terms]) OR ((fibrin) AND glue)))) OR fibrin sealant) OR fibrin coating) OR Tisseel)) AND (("Anastomosis, Surgical”[Mesh]) OR anastomo*). Likewise, a search in the Cochrane database was performed using the following search string: (Fibrin glue OR Fibrin sealant) AND (Anastomoses OR Anastomosis). The reference list of identified studies was hand-searched for additional studies.

\section{Definition of $F G$}

FG is mainly derived from blood plasma and contains fibrinogen and thrombin. Further ingredients are anti-fibrinolytic agents (such as aprotinin) and calcium chloride. Some fibrin sealants also contain factor XIII. FG is available as a fluid or bound to a mesh. It can be either commercially produced [49-51] or produced locally in the clinical setting from human or animal blood. 
Nordentoft et al.: Fibrin Glue Does Not Improve Healing of Gastrointestina Anastomoses: A Systematic Review

\section{Study Selection}

A study had to fulfill the following 3 criteria in order to be included in the analysis: (1) it had to involve gastrointestinal anastomoses (esophagus, stomach, bile system, duodenum, pancreas, small intestine, colon or rectum), which may have been performed in any way, i.e. hand-sewn, stapled or glued (sutureless), and should have been conducted on live humans or animals; (2) it had to use any kind of application of FG on the anastomosis according to the description of FG above, and (3) it had to evaluate the healing of the anastomoses by either histological or biochemical methods.

A study was excluded if one of the following criteria was fulfilled: (1) no control group in the study design; (2) anastomoses in the control group were not similar to those in the FG group; (3) no well-described method for the evaluation of histological or biochemical healing, and (4) no full-text available.

The studies identified in the search were screened by title and abstract for eligibility. After this screening, the full-text of the remaining studies were read and assessed according to the above-mentioned criteria. Eligible studies were included in the qualitative synthesis. In order to avoid bias, the selection procedure was performed independently by two of the authors (T.N. and M.P.A.). In case of disagreement, the disputed studies were discussed among all authors, and a consensus was achieved.

\section{Data Extraction}

The following data were extracted from the included studies: author names and year of publication; type of study (human or experimental); animals used (experimental studies); localization of anastomoses; type of anastomoses; intervention; type of FG; use of randomization; type(s) of histological or biochemical evaluation of healing; effect of FG, and conclusion of the study.

Data were extracted directly from the included articles. In one case, additional information about the significance of the results was obtained from the authors [54]. The primary outcome of the present review was the healing effect of FG on anastomoses.

\section{Results}

In the qualitative synthesis, 28 studies were included (fig. 1). These studies were all experimental studies, since no human studies applied histological or biochemical evaluation of healing. Of these studies, 23 were performed in rats, 2 in rabbits, 2 in pigs and 1 in mice. Anastomoses were performed on the colon in 20 studies, on the small intestine in 6 and on the esophagus in 2 studies. Of the 28 studies, 17 were randomized. Various methods of histological or biochemical evaluation of healing were used (table 1).

The application of FG for sealing, coating, reinforcement or other application to the anastomoses were obligate for studies included in the qualitative synthesis. Different liquid or mesh-bound FG were used in the studies. Liquid FG (Tisseel ${ }^{\mathrm{TM}}$, Tissucol ${ }^{\mathrm{TM}}$, Guang Zhou Bioseal $^{\mathrm{TM}}$, Beriplast ${ }^{\mathrm{TM}}$ ) were used in 23 studies, while mesh-bound FG (TachoSil ${ }^{\mathrm{TM}}$, TachoCom) were used in 5 studies.

\section{Effect on Healing}

In 7 of the 28 studies, a positive effect of FG on healing was found [55-61], while 8 studies reported a negative effect [62-69] and 11 studies found no effect [54, 70-79]. Furthermore, 2 studies reported unclear results [80, 81] (table 2).

Different types of anastomoses, animals and FG were used in the included studies (table 3). In the group of studies with positive results, 3 of 7 (43\%) anastomoses were made on the small intestine, while this was only the case in 11 and $18 \%$ of the groups reporting negative results and no effect, respectively. No differences were found relating to the type of animal or the type of FG used. 


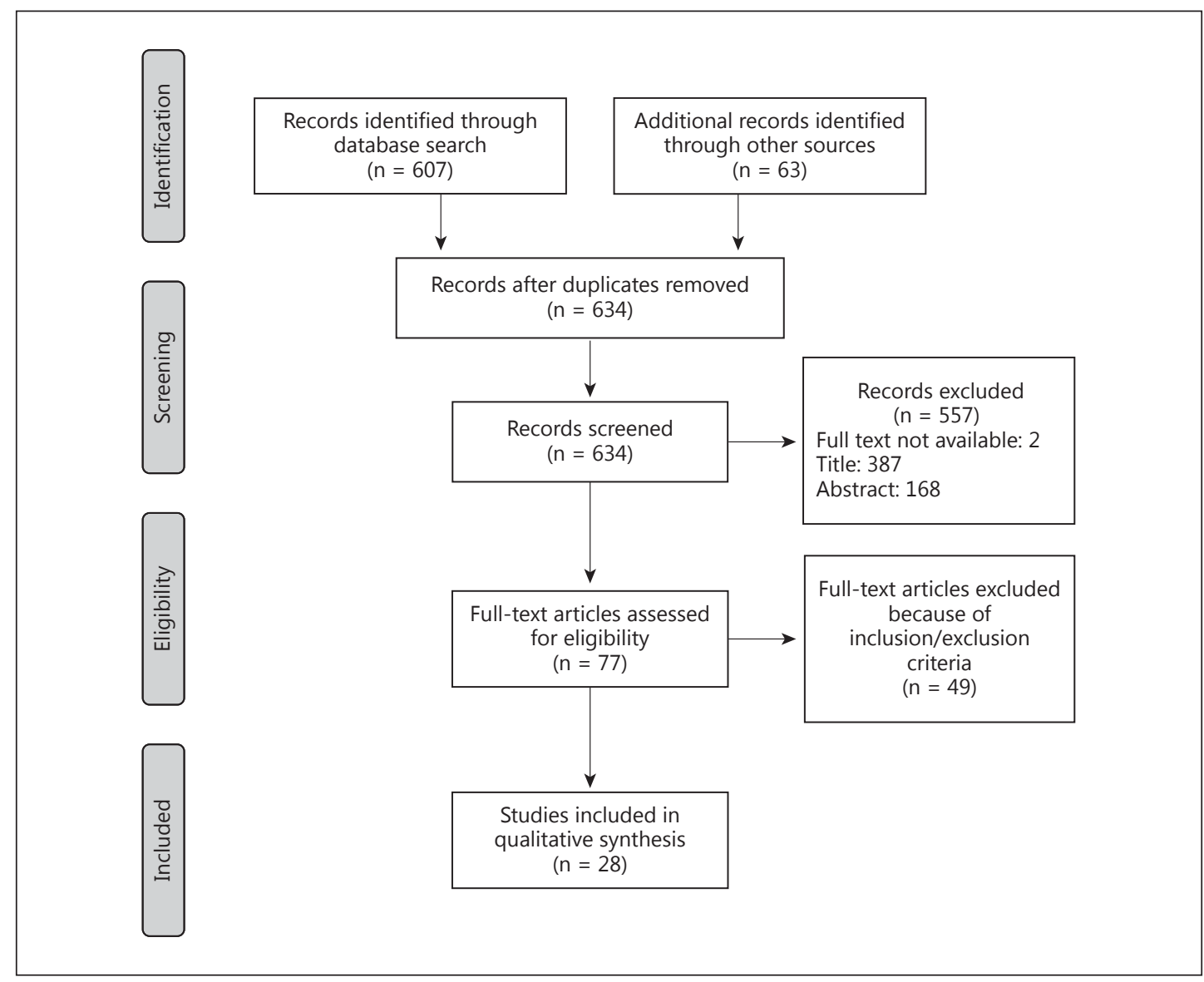

Fig. 1. Flow diagram.

\section{Discussion}

The results from the analyzed studies were conflicting. Of the 28 studies included, 7 studies revealed a positive effect of FG on histological or biochemical healing of gastrointestinal anastomoses, 8 studies found a negative effect and 13 studies found no effect or had unclear results.

Several different designs were used in the included studies, e.g. different experimental animals, anastomoses on different parts of the gastrointestinal canal, different kinds of FG and different observation periods. In addition, various methods for the evaluation of healing have been used. These differences might explain the conflicting results. When comparing the group of studies with a positive effect on healing with the group of studies with a negative effect, it seems that a larger proportion of positive results came from studies on the small intestine. In this group, 3 out of 7 studies were made on the small intestine in contrast to the group of studies with negative results, where only 1 of 8 studies was made on both the ileum and colon, and the remaining 7 studies used the colon.

The mechanisms behind the healing properties of FG, or lack thereof, are unknown. In 1 study on colonic anastomoses in rats, compromised healing after FG sealing was demonstrated, and these findings were hypothesized to be due to an inflammatory reaction caused by the sealing [64]. In 2 other studies, it was found that FG sealing inhibited healing of normal 
Nordentoft et al.: Fibrin Glue Does Not Improve Healing of Gastrointestinal Anastomoses: A Systematic Review

Table 1. Types of examinations

\begin{tabular}{|c|c|c|}
\hline Name & Type & Description \\
\hline Hydroxyproline level & Biochemical extract analysis & Indicator of collagen content [93-97] \\
\hline $\begin{array}{l}\text { Ehrlich-Hunt score or } \\
\text { modified Ehrlich-Hunt } \\
\text { score }\end{array}$ & Histological analysis & $\begin{array}{l}\text { Histological score estimating inflammatory cells, fibroblasts, } \\
\text { neovascularization and collagen content on a scale from } 0 \text { to } 4[98,99]\end{array}$ \\
\hline Collagen ratio I/III & $\begin{array}{l}\text { Histological or biochemical } \\
\text { extract analysis (qPCR) }\end{array}$ & $\begin{array}{l}\text { Increased content of collagen III indicates formation of granulation } \\
\text { tissue/regeneration/tissue repair [100] }\end{array}$ \\
\hline $\begin{array}{l}\text { MMP } 2.9 \\
\text { and/or } 13 \text { level }\end{array}$ & $\begin{array}{l}\text { Histological or biochemical } \\
\text { extract analysis (zymogram or } \\
\text { qPCR) }\end{array}$ & Increased MMP level during tissue repair [94, 100-102] \\
\hline Sirius red staining & Histological analysis & Histochemical collagen staining \\
\hline$\alpha$-SMA & Histological analysis & Specific detection of $\alpha$-SMA occurring in granulation tissue \\
\hline $\begin{array}{l}\text { Estimation of } \\
\text { neoangiogenesis }\end{array}$ & Histological analysis & $\begin{array}{l}\text { Estimation of neoangiogenesis in a systematical and/or blinded way; } \\
\text { reflects tissue repair }\end{array}$ \\
\hline $\begin{array}{l}\text { Estimation of fibroblast } \\
\text { proliferation }\end{array}$ & Histological analysis & $\begin{array}{l}\text { Estimation of fibroblast proliferation in a systematical and/or blinded } \\
\text { way; reflects tissue repair }\end{array}$ \\
\hline Histological evaluation & Histological analysis & Simple histological evaluation in a systematical and/or blinded way \\
\hline
\end{tabular}

colon anastomoses in rats $[65,69]$. The hypothesis there was an increased inflammatory activity, which caused an increased production of collagenase and thereby reduced collagen concentration. In another study by the same authors, antibiotics were added to the FG sealant, causing reduced inflammation and increased bursting pressure and collagen content [68]. In line with this, another study suggested that impaired healing after sealing was due to the intraluminal confinement of bacteria together with a reduced peritoneal contact of the anastomoses [72]. These findings suggest that impaired healing may be due to inflammation and/ or foreign body reaction caused by the sealing, by bacteria from the colon or both. This is in accordance with studies suggesting that fibrin matrices impair the phagocytic killing of bacteria by neutrophils [82] and impede macrophage migration [83]. In studies focusing on wound healing in general, infection was found to have an undesirable influence on the healing process as well [84]. These hypotheses are in accordance with the fact that more studies investigating anastomoses in the small intestine found a positive effect on healing compared with studies investigating anastomoses in the colon, since the bacterial content may be larger in the colon than in the small intestine.

To date, several methods for evaluating the integrity of an anastomosis have been proposed and tested. Most of these methods have focused on the macroscopic results such as anastomotic leakage, anastomotic strength and bursting pressure, but not on the healing process per se. Among the 28 studies included in the present review, which all focused on both healing and mechanical properties, it appears that the results on these macroscopic/ mechanical properties differed considerably from the healing results. A total of 14 studies found a positive effect on anastomotic leakage, anastomotic strength or bursting pressure $[55-61,63,70,75-78,80]$, while only 2 studies found a negative effect on these end points $[69,71]$. Of the 8 studies with no effect on healing, 6 studies revealed a positive effect on bursting pressure or anastomotic strength $[70,75-78,80]$. Similar findings were seen in the group of studies reporting a negative effect on healing, where 1 study found a positive effect on bursting pressure and anastomotic strength [63], 6 studies found no effect on these 
Table 2. Studies included in the qualitative synthesis

\begin{tabular}{|c|c|c|c|c|c|}
\hline Study & Animal & $\begin{array}{l}\text { Type of } \\
\text { anastomoses }\end{array}$ & $\begin{array}{l}\text { Observation } \\
\text { time, days }\end{array}$ & $\begin{array}{l}\text { Type of histological } \\
\text { or biochemical } \\
\text { evaluation of } \\
\text { healing }\end{array}$ & Conclusion \\
\hline $\begin{array}{l}\text { Senol } \\
\text { et al. [55] }\end{array}$ & Rats $(n=40)$ & Colon & 10 & $\begin{array}{l}\text { Hydroxyproline, } \\
\text { Ehrlich-Hunt }\end{array}$ & $\begin{array}{l}\text { FG improved } \\
\text { anastomotic healing }\end{array}$ \\
\hline $\begin{array}{l}\text { Subhas } \\
\text { et al. [56] }\end{array}$ & Rats $(n=70)$ & Colon & 3,5 & $\begin{array}{l}\text { Neoangiogenesis, } \\
\text { fibroblast } \\
\text { proliferation }\end{array}$ & $\begin{array}{l}\text { FG improved } \\
\text { anastomotic healing }\end{array}$ \\
\hline $\begin{array}{l}\text { Pantelis } \\
\text { et al. [57] }\end{array}$ & Mice $(n=206)$ & Colon & $2,5,14$ & $\begin{array}{l}\text { Anastomotic } \\
\text { healing score, } \\
\text { collagen I/III } \\
\text { expression, } \\
\text { hydroxyproline }\end{array}$ & $\begin{array}{l}\text { FG improved } \\
\text { anastomotic healing }\end{array}$ \\
\hline $\begin{array}{l}\text { Wang } \\
\text { et al. [58] }\end{array}$ & Pigs $(n=63)$ & $\begin{array}{l}\text { Small } \\
\text { intestine }\end{array}$ & 10 & $\begin{array}{l}\text { Hydroxyproline, } \\
\text { Ehrlich-Hunt }\end{array}$ & $\begin{array}{l}\text { FG improved } \\
\text { anastomotic healing }\end{array}$ \\
\hline $\begin{array}{l}\text { Yilmaz } \\
\text { et al. [61] }\end{array}$ & Rats $(n=48)$ & Colon & 4 & $\begin{array}{l}\text { Collagen deposition, } \\
\text { fibroblast activity }\end{array}$ & $\begin{array}{l}\text { FG improved } \\
\text { anastomotic healing }\end{array}$ \\
\hline $\begin{array}{l}\text { Saclarides } \\
\text { et al. [60] }\end{array}$ & Rats $(n=69)$ & Ileum & 7 & Hydroxyproline & $\begin{array}{l}\text { FG improved } \\
\text { anastomotic healing } \\
\text { of irradiated } \\
\text { anastomoses }\end{array}$ \\
\hline $\begin{array}{l}\mathrm{Li} \\
\text { et al. [59] }\end{array}$ & Rats $(\mathrm{n}=360)$ & Ileum & $1,3,5$ & Hydroxyproline & $\begin{array}{l}\text { Increased healing in } \\
\text { FG group on days } 3 \\
\text { and } 5 \text {, no difference } \\
\text { on day } 1\end{array}$ \\
\hline $\begin{array}{l}\text { van der Vijver } \\
\text { et al. [62] }\end{array}$ & Rats $(\mathrm{n}=108)$ & $\begin{array}{l}\text { Ileum and } \\
\text { colon }\end{array}$ & $3,5,7$ & $\begin{array}{l}\text { Hydroxyproline, } \\
\text { MMP, collagen } \\
\text { histology (Sirius } \\
\text { red) }\end{array}$ & $\begin{array}{l}\text { FG had a negative } \\
\text { effect on } \\
\text { anastomotic healing }\end{array}$ \\
\hline $\begin{array}{l}\text { Akgun } \\
\text { et al.[63] }\end{array}$ & Rats $(\mathrm{n}=38)$ & Colon & 3 & $\begin{array}{l}\text { Collagen deposition, } \\
\text { histology }\end{array}$ & $\begin{array}{l}\text { FG had a negative } \\
\text { effect on } \\
\text { anastomotic healing }\end{array}$ \\
\hline $\begin{array}{l}\text { Ozel } \\
\text { et al. [64] }\end{array}$ & Rats $(n=36)$ & Colon & 3,7 & $\begin{array}{l}\text { Collagen deposition, } \\
\text { neovascularity, } \\
\text { fibroblast activity }\end{array}$ & $\begin{array}{l}\text { FG had a negative } \\
\text { effect on } \\
\text { anastomotic healing }\end{array}$ \\
\hline $\begin{array}{l}\text { Van der Ham } \\
\text { et al. [65] }\end{array}$ & Rats $(\mathrm{n}=120)$ & Colon & $2,4,7$ & $\begin{array}{l}\text { Hydroxyproline, } \\
\text { collagen } \\
\text { concentration }\end{array}$ & $\begin{array}{l}\text { FG had a negative } \\
\text { effect on } \\
\text { anastomotic healing }\end{array}$ \\
\hline $\begin{array}{l}\text { Van der Ham } \\
\text { et al. [66] }\end{array}$ & Rats $(\mathrm{n}=120)$ & Colon & $2,4,7$ & $\begin{array}{l}\text { Collagen } \\
\text { concentration, } \\
\text { hydroxyproline }\end{array}$ & $\begin{array}{l}\text { FG had a negative } \\
\text { effect on } \\
\text { anastomotic healing }\end{array}$ \\
\hline $\begin{array}{l}\text { Van der Ham } \\
\text { et al. [67] }\end{array}$ & Rats $(\mathrm{n}=120)$ & Colon & $2,4,7$ & $\begin{array}{l}\text { Collagen } \\
\text { concentration }\end{array}$ & $\begin{array}{l}\text { FG had a negative } \\
\text { effect on } \\
\text { anastomotic healing }\end{array}$ \\
\hline $\begin{array}{l}\text { Van der Ham } \\
\text { et al. [68] }\end{array}$ & Rats $(n=90)$ & Colon & $2,4,7$ & $\begin{array}{l}\text { Collagen } \\
\text { concentration, } \\
\text { hydroxyproline }\end{array}$ & $\begin{array}{l}\text { FG had a negative } \\
\text { effect on } \\
\text { anastomotic healing }\end{array}$ \\
\hline $\begin{array}{l}\text { Van der Ham } \\
\text { et al. [69] }\end{array}$ & Rats $(\mathrm{n}=90)$ & Colon & $2,4,7$ & Hydroxyproline & $\begin{array}{l}\text { FG had a negative } \\
\text { effect on } \\
\text { anastomotic healing }\end{array}$ \\
\hline
\end{tabular}


Table 2 (continued)

\begin{tabular}{|c|c|c|c|c|c|}
\hline Study & Animal & $\begin{array}{l}\text { Type of } \\
\text { anastomoses }\end{array}$ & $\begin{array}{l}\text { Observation } \\
\text { time, days }\end{array}$ & $\begin{array}{l}\text { Type of histological } \\
\text { or biochemical } \\
\text { evaluation of } \\
\text { healing }\end{array}$ & Conclusion \\
\hline $\begin{array}{l}\text { Ayhan } \\
\text { et al. [70] }\end{array}$ & Rats (n = 28) & Colon & 6 & Ehrlich-Hunt & $\begin{array}{l}\text { FG did not affect } \\
\text { anastomotic healing }\end{array}$ \\
\hline $\begin{array}{l}\text { Chmelnik } \\
\text { et al. [71] }\end{array}$ & Rats $(\mathrm{n}=73)$ & Ileum & 2,10 & Ehrlich-Hunt & $\begin{array}{l}\text { FG did not affect } \\
\text { anastomotic healing }\end{array}$ \\
\hline $\begin{array}{l}\text { Schreinemacher } \\
\text { et al. [72] }\end{array}$ & Rats $(n=61)$ & Colon & 3,7 & $\begin{array}{l}\text { Collagen content } \\
\text { (Sirius red) }\end{array}$ & $\begin{array}{l}\text { FG did not affect } \\
\text { anastomotic healing }\end{array}$ \\
\hline $\begin{array}{l}\text { Giuratrabocchetta } \\
\text { et al. [54] }\end{array}$ & $\begin{array}{l}\text { Rabbits } \\
(\mathrm{n}=10)\end{array}$ & Colon & 15 & Ehrlich-Hunt & $\begin{array}{l}\text { FG did not affect } \\
\text { anastomotic healing }\end{array}$ \\
\hline $\begin{array}{l}\text { Nordentoft } \\
\text { et al. [73] }\end{array}$ & Pigs (n = 11) & $\begin{array}{l}\text { Small } \\
\text { intestine }\end{array}$ & $\begin{array}{l}7,14,21 \\
28,35,42\end{array}$ & $\begin{array}{l}\text { Histological } \\
\text { examination }\end{array}$ & $\begin{array}{l}\text { FG did not affect } \\
\text { anastomotic healing }\end{array}$ \\
\hline $\begin{array}{l}\text { Li } \\
\text { et al. [74] }\end{array}$ & Rats $(n=300)$ & Colon & $\begin{array}{l}3,5,7 \\
10,14\end{array}$ & $\begin{array}{l}\text { Hydroxyproline } \\
\text { content }\end{array}$ & $\begin{array}{l}\text { FG did not affect } \\
\text { anastomotic healing }\end{array}$ \\
\hline $\begin{array}{l}\text { Kanellos } \\
\text { et al. [75] }\end{array}$ & Rats $(n=60)$ & Colon & 8 & $\begin{array}{l}\text { Ehrlich-Hunt, } \\
\text { collagen content }\end{array}$ & $\begin{array}{l}\text { FG did not affect } \\
\text { anastomotic healing }\end{array}$ \\
\hline $\begin{array}{l}\text { Kanellos } \\
\text { et al. [78] }\end{array}$ & Rats $(n=36)$ & Colon & 8 & Ehrlich-Hunt & $\begin{array}{l}\text { FG did not affect } \\
\text { anastomotic healing }\end{array}$ \\
\hline $\begin{array}{l}\text { Kanellos } \\
\text { et al. [76] }\end{array}$ & Rats $(n=60)$ & Colon & 8 & $\begin{array}{l}\text { Ehrlich-Hunt, } \\
\text { collagen content }\end{array}$ & $\begin{array}{l}\text { FG induced no } \\
\text { difference in } \\
\text { healing, but might } \\
\text { protect the } \\
\text { anastomoses from } \\
\text { adverse effects }\end{array}$ \\
\hline $\begin{array}{l}\text { Kanellos } \\
\text { et al. [77] }\end{array}$ & Rats $(n=46)$ & Colon & 8 & $\begin{array}{l}\text { Ehrlich-Hunt, } \\
\text { collagen content }\end{array}$ & $\begin{array}{l}\text { FG induced no } \\
\text { difference in } \\
\text { healing, but might } \\
\text { protect the } \\
\text { anastomoses from } \\
\text { adverse effects }\end{array}$ \\
\hline $\begin{array}{l}\text { Karahasanoglu } \\
\text { et al. [79] }\end{array}$ & Rats $(n=40)$ & Colon & 4 & Hydroxyproline & $\begin{array}{l}\text { FG did not affect } \\
\text { anastomotic healing }\end{array}$ \\
\hline $\begin{array}{l}\text { Yurtcu } \\
\text { et al. [81] }\end{array}$ & $\begin{array}{l}\text { Rabbits } \\
(\mathrm{n}=24)\end{array}$ & $\begin{array}{l}\text { Esophago- } \\
\text { gastric }\end{array}$ & 8 & $\begin{array}{l}\text { Hydroxyproline, } \\
\text { histological wound } \\
\text { healing score }\end{array}$ & $\begin{array}{l}\text { Unclear results, } \\
\text { maybe positive effect } \\
\text { on healing }\end{array}$ \\
\hline $\begin{array}{l}\text { Verhage } \\
\text { et al. [80] }\end{array}$ & Rats $(\mathrm{n}=54)$ & $\begin{array}{l}\text { Esophago- } \\
\text { gastric }\end{array}$ & 3,7 & $\begin{array}{l}\text { Sirius red and } \\
\alpha \text {-SMA staining } \\
\text { score }\end{array}$ & $\begin{array}{l}\text { Unclear results, } \\
\text { maybe positive effect } \\
\text { on healing }\end{array}$ \\
\hline
\end{tabular}

$\alpha$-SMA = Alpha smooth muscle actin; MMP = matrix metalloproteinase.

mechanical end points [62, 64-68] and only 1 study found a negative effect on bursting pressure [69]. On the contrary, all of the 7 studies that reported a positive effect on healing also showed a positive effect on the mechanical end points [55-61].

These results are in line with those from other studies on sealing of gastrointestinal anastomoses with FG $[47,48]$ that were not included in the present review due to a lack or inadequate evaluation of healing. The results from these studies are inconsistent, but a number of 
Table 3. Type of anastomoses, animals and FG associated with sealing effects

\begin{tabular}{|c|c|c|c|c|}
\hline Conclusion of study & Studies, $\mathrm{n}$ & Anastomotic sites & Animals & Types of FG \\
\hline Positive effect [55-61] & 7 & $\begin{array}{l}\text { Colon: } 4 \\
\text { Small intestine: } 3 \\
\text { Esophagus: } 0\end{array}$ & $\begin{array}{l}\text { Mice: } 1 \\
\text { Rat: } 5 \\
\text { Rabbit: } 0 \\
\text { Pig: } 1\end{array}$ & $\begin{array}{l}\text { Mesh-bound: } 1 \\
\text { Liquid: } 6\end{array}$ \\
\hline Negative effect [62-69] & 8 & $\begin{array}{l}\text { Colon*: } 8 \\
\text { Small intestine*: } 1 \\
\text { Esophagus: } 0\end{array}$ & $\begin{array}{l}\text { Mice: } 0 \\
\text { Rat: } 8 \\
\text { Rabbit: } 0 \\
\text { Pig: } 0\end{array}$ & $\begin{array}{l}\text { Mesh-bound: } 1 \\
\text { Liquid: } 7\end{array}$ \\
\hline No effect $[54,70-79]$ & 11 & $\begin{array}{l}\text { Colon: } 9 \\
\text { Small intestine: } 2 \\
\text { Esophagus: } 0\end{array}$ & $\begin{array}{l}\text { Mice: } 0 \\
\text { Rat: } 9 \\
\text { Rabbit: } 1 \\
\text { Pig: } 1\end{array}$ & $\begin{array}{l}\text { Mesh-bound: } 2 \\
\text { Liquid: } 9\end{array}$ \\
\hline Unclear $[80,81]$ & 2 & $\begin{array}{l}\text { Colon: } 0 \\
\text { Small intestine: } 0 \\
\text { Esophagus: } 2\end{array}$ & $\begin{array}{l}\text { Mice: } 0 \\
\text { Rat: } 1 \\
\text { Rabbit: } 1 \\
\text { Pig: } 0\end{array}$ & $\begin{array}{l}\text { Mesh-bound: } 1 \\
\text { Liquid: } 1\end{array}$ \\
\hline
\end{tabular}

human and experimental studies have revealed positive effects on anastomotic leakage, bursting pressure or anastomotic strength. In a randomized study on esophageal anastomoses in infants born with esophageal atresia, a significantly reduced incidence of anastomotic leakage and stricture was found in the group sealed with FG [85]. Two human studies on FG sealing of anastomoses in patients with Roux-en-Y gastric bypass found a nonsignificantly decreased incidence of anastomotic leakage in the sealing group [86, 87]. Another human study on anastomotic leakage after laparoscopic resection of rectal cancer found a leakage rate of $5.8 \%$ in the FG-sealed group compared with $10.9 \%$ in the nonsealed group. However, this difference was not statistically significant [88]. Beside the studies included in this review, other experimental studies have examined the mechanical effect of sealing with FG. In a model of anastomotic leakage of stapled gastrojejunostomy made on swine, a significantly reduced anastomotic leakage and abscess rate was found in the group sealed with FG compared with controls [89], and a comparable study found similar results [90].

The current evidence, in combination with the results of the present review, indicates that the potential positive effect of sealing is most likely due to a physical/mechanical effect and not due to improved healing of the anastomosis. This is in line with other suggested hypotheses on the strength of sealed anastomoses. In a study on rat esophagus anastomoses, it was found that increased anastomotic strength was mainly due to a mechanical strengthening of the anastomoses by the sealant [80]. Four of the studies analyzed in this review emphasize that FG, besides its adhesive properties, is water-resistant and thus constitutes a physical barrier around the anastomosis $[59,70,75,76]$. Another study found that sealing of colonic anastomoses in rats with FG had a negative effect on healing but a positive effect on bursting pressure and anastomotic strength, suggesting that this may be due to the closure of microperforations [63].

The present paper has certain limitations. No bias assessment of the individual studies was performed in this review. Suitable tools for bias evaluation of studies exist for human 
Nordentoft et al.: Fibrin Glue Does Not Improve Healing of Gastrointestinal

Anastomoses: A Systematic Review

interventional and observational clinical studies [91]. However, there are no validated methods for experimental studies. An important limitation of this review may be the high degree of heterogeneity between the studies with regard to the evaluation of healing, study design and outcome measures. The microscopical healing was not the primary end point in any of the studies. Hence, this was sparsely and occasionally unsystematically described, and a meta-analysis was not possible. Such heterogeneity is known to limit the comparability of studies, which may be reflected in the conflicting results reported in the included studies [91]. Publication bias is present for all types of study designs, but it is almost four times more common in experimental studies than in randomized controlled trials [92]. Thus, the experimental design of the included studies may be subject to a high degree of publication bias, which may overestimate the effect of FG. Therefore, despite the high proportion of studies reporting negative results included in the present review, this proportion may even be higher in the absence of publication bias. However, as we did not perform a meta-analysis with funnel plots, the degree of publication bias remains unknown. In general, selection bias is less common in experimental interventional studies due to a high degree of similarity between the animals compared with patients in clinical trials. Moreover, $61 \%$ of the included studies were randomized, which further minimizes the risk of selection bias. Another limitation is that the studies did not compare similar kinds of sealing but only compared sealing with or without FG. Thus, it remains unclear if the effect on macroscopical healing, e.g. bursting pressure, was due to a formation of adhesions around the anastomoses as a result of the sealing, or due to FG per se. Finally, none of the studies was performed on humans, which must be considered a limitation for clinical applicability.

From the present review, we conclude that FG does not have a consistent positive influence on the healing of gastrointestinal anastomoses. If FG has such an effect, this effect might be impaired by an infected environment such as in the colon. It is consequently plausible that the positive effect of FG sealing of gastrointestinal anastomoses, if there is any, is due to a mechanical sealing influence and not due to improved healing per se. Thus, future research on sealing with FG could focus on the mechanical properties of the sealing.

\section{Disclosure Statement}

The authors have no conflicts of interest to declare. There are no sponsorship or funding arrangements related to this research.

\section{References}

1 Branagan G, Finnis D: Prognosis after anastomotic leakage in colorectal surgery. Dis Colon Rectum 2005;48: 1021-1026.

-2 Buchs NC, Gervaz P, Secic M, Bucher P, Mugnier-Konrad B, Morel P: Incidence, consequences, and risk factors for anastomotic dehiscence after colorectal surgery: a prospective monocentric study. Int J Colorectal Dis 2008;23:265-270.

-3 Eberhardt JM, Kiran RP, Lavery IC: The impact of anastomotic leak and intra-abdominal abscess on cancerrelated outcomes after resection for colorectal cancer: a case control study. Dis Colon Rectum 2009;52:380386.

4 Kube R, Mroczkowski P, Granowski D, Benedix F, Sahm M, Schmidt U, Gastinger I, Lippert H: Anastomotic leakage after colon cancer surgery: a predictor of significant morbidity and hospital mortality, and diminished tumour-free survival. Eur J Surg Oncol 2010;36:120-124.

5 Marra F, Steffen T, Kalak N, Warschkow R, Tarantino I, Lange J, Zund M: Anastomotic leakage as a risk factor for the long-term outcome after curative resection of colon cancer. Eur J Surg Oncol 2009;35:1060-1064.

6 Ptok H, Marusch F, Meyer F, Schubert D, Gastinger I, Lippert H: Impact of anastomotic leakage on oncological outcome after rectal cancer resection. Br J Surg 2007; 94:1548-1554.

7 Thornton M, Joshi H, Vimalachandran C, Heath R, Carter P, Gur U, Rooney P: Management and outcome of colorectal anastomotic leaks. Int J Colorectal Dis 2011;26:313-320. 
Nordentoft et al.: Fibrin Glue Does Not Improve Healing of Gastrointestinal

Anastomoses: A Systematic Review

-8 Rutegard M, Lagergren P, Rouvelas I, Lagergren J: Intrathoracic anastomotic leakage and mortality after esophageal cancer resection: a population-based study. Ann Surg Oncol 2012;19:99-103.

-9 Chambers WM, Mortensen NJ: Postoperative leakage and abscess formation after colorectal surgery. Best Pract Res Clin Gastroenterol 2004;18:865-880.

-10 Hyman N, Manchester TL, Osler T, Burns B, Cataldo PA: Anastomotic leaks after intestinal anastomosis: it's later than you think. Ann Surg 2007;245:254-258.

11 Walker KG, Bell SW, Rickard MJ, Mehanna D, Dent OF, Chapuis PH, Bokey EL: Anastomotic leakage is predictive of diminished survival after potentially curative resection for colorectal cancer. Ann Surg 2004;240:255-259.

12 Law WL, Choi HK, Lee YM, Ho JW, Seto CL: Anastomotic leakage is associated with poor long-term outcome in patients after curative colorectal resection for malignancy. J Gastrointest Surg 2007;11:8-15.

$\checkmark 13$ Kofoed SC, Calatayud D, Jensen LS, Jensen MV, Svendsen LB: Intrathoracic anastomotic leakage after gastroesophageal cancer resection is associated with reduced long-term survival. World J Surg 2014;38:114-119.

14 McArdle CS, McMillan DC, Hole DJ: Impact of anastomotic leakage on long-term survival of patients undergoing curative resection for colorectal cancer. Br J Surg 2005; 92:1150-1154.

15 Dorricott NJ, Baddeley RM, Keighley MR, Lee J, Oates GD, Alexander-Williams J: Complications of rectal anastomoses with end-to-end anastomosis (EEA) stapling instrument. Clinical and radiological leak rates and some practical hints. Ann R Coll Surg Engl 1982;64:171-174.

16 Karanjia ND, Corder AP, Bearn P, Heald RJ: Leakage from stapled low anastomosis after total mesorectal excision for carcinoma of the rectum. Br J Surg 1994;81:1224-1226.

-17 Nesbakken A, Nygaard K, Lunde OC: Outcome and late functional results after anastomotic leakage following mesorectal excision for rectal cancer. Br J Surg 2001;88:400-404.

18 Adams W, Ctercteko G, Bilous M: Effect of an omental wrap on the healing and vascularity of compromised intestinal anastomoses. Dis Colon Rectum 1992;35:731-738.

19 Agnifili A, Schietroma M, Carloni A, Mattucci S, Caterino G, Lygidakis NJ, Carlei F: The value of omentoplasty in protecting colorectal anastomosis from leakage. A prospective randomized study in 126 patients. Hepatogastroenterology 2004;51:1694-1697.

-20 Aysan E, Dincel 0, Bektas H, Alkan M: Polypropylene mesh covered colonic anastomosis. Results of a new anastomosis technique. Int J Surg 2008;6:224-229.

21 Byrne DJ, Hardy J, Wood RA, McIntosh R, Hopwood D, Cuschieri A: Adverse influence of fibrin sealant on the healing of high-risk sutured colonic anastomoses. J R Coll Surg Edinb 1992;37:394-398.

22 Fekete F, Gayet B, Panis Y: Contribution of fibrin glue to the reinforcement of esophageal anastomoses (in French). Presse Med 1992;21:157-159.

-23 Fernandez FL, Tejero E, Tieso A: Randomized trial of fibrin glue to seal mechanical oesophagojejunal anastomosis. Br J Surg 1996;83:40-41.

24 Gulati SM, Thusoo TK, Kakar A, Iyenger B, Pandey KK: Comparative study of free omental, peritoneal, Dacron velour, and Marlex mesh reinforcement of large-bowel anastomosis: an experimental study. Dis Colon Rectum 1982;25:517-521.

25 Henne-Bruns D, Kreischer HP, Schmiegelow P, Kremer B: Reinforcement of colon anastomoses with polyglycolic acid mesh: an experimental study. Eur Surg Res 1990;22:224-230.

-26 Hjortrup A, Nordkild P, Christensen T, Sjontoft E, Kjaergaard J: Rectal anastomosis with application of luminal fibrin adhesive in the rectum of dogs. An experimental study. Dis Colon Rectum 1989;32:422-425.

27 Hulkko OA, Haukipuro KA, Laitinen ST: Fibrin glue protection of primary anastomosis in the obstructed left colon. An experimental study on the rat. Acta Chir Scand 1988;154:49-52.

28 Kanellos I, Mantzoros I, Goulimaris I, Zacharakis E, Zavitsanakis A, Betsis D: Effects of the use of fibrin glue around the colonic anastomosis of the rat. Tech Coloproctol 2003;7:82-84.

-29 Kanellos I, Mantzoros I, Demetriades H, Kalfadis S, Kelpis T, Sakkas L, Betsis D: Healing of colon anastomoses covered with fibrin glue after immediate postoperative intraperitoneal administration of 5-fluorouracil. Dis Colon Rectum 2004;47:510-515.

-30 Katsikas D, Sechas M, Antypas G, Floudas P, Moshovos K, Gogas J, Rigas A, Papacharalambous N, Skalkeas G: Beneficial effect of omental wrapping of unsafe intestinal anastomoses. An experimental study in dogs. Int Surg 1977;62:435-437.

-31 Lillemoe KD, Cameron JL, Kim MP, Campbell KA, Sauter PK, Coleman JA, Yeo CJ: Does fibrin glue sealant decrease the rate of pancreatic fistula after pancreaticoduodenectomy? Results of a prospective randomized trial. J Gastrointest Surg 2004;8:766-772.

32 Liu CD, Glantz GJ, Livingston EH: Fibrin glue as a sealant for high-risk anastomosis in surgery for morbid obesity. Obes Surg 2003;13:45-48.

33 McLachlin AD, Olsson LS, Pitt DF: Anterior anastomosis of the rectosigmoid colon: an experimental study. Surgery 1976;80:306-311.

-34 Merad F, Hay JM, Fingerhut A, Flamant Y, Molkhou JM, Laborde Y: Omentoplasty in the prevention of anastomotic leakage after colonic or rectal resection: a prospective randomized study in 712 patients. French Associations for Surgical Research. Ann Surg 1998;227:179-186.

-35 Moazami N, Oz MC, Bass LS, Treat MR: Reinforcement of colonic anastomoses with a laser and dye-enhanced fibrinogen. Arch Surg 1990;125:1452-1454.

-36 Oka H, Harrison RC, Burhenne HJ: Effect of a biologic glue on the leakage rate of experimental rectal anastomoses. Am J Surg 1982;143:561-564. 
Pierie JP, de Graaf PW, van Dijk M, Renooij W, van Vroonhoven TJ, Obertop H: Improved healing of extraperitoneal intestinal anastomoses in the early phase when surrounded by omentum. Dig Surg 2000;17:487-491.

-38 Pommergaard HC, Achiam MP, Rosenberg J: External coating of colonic anastomoses: a systematic review. Int J Colorectal Dis 2012;27:1247-1258.

-39 Saclarides TJ, Woodard DO, Bapna M, Economou SG: Fibrin glue improves the healing of irradiated bowel anastomoses. Dis Colon Rectum 1992;35:249-252.

40 Sapala JA, Wood MH, Schuhknecht MP: Anastomotic leak prophylaxis using a vapor-heated fibrin sealant: report on 738 gastric bypass patients. Obes Surg 2004;14:35-42.

41 Tocchi A, Mazzoni G, Lepre L, Costa G, Liotta G, Agostini N, Miccini M: Prospective evaluation of omentoplasty in preventing leakage of colorectal anastomosis. Dis Colon Rectum 2000;43:951-955.

42 van der Ham AC, Kort WJ, Weijma IM, van den Ingh HF, Jeekel J: Effect of fibrin sealant on the healing colonic anastomosis in the rat. Br J Surg 1991;78:49-53.

-43 van der Ham AC, Kort WJ, Weijma IM, van den Ingh HF, Jeekel H: Healing of ischemic colonic anastomosis: fibrin sealant does not improve wound healing. Dis Colon Rectum 1992;35:884-891.

44 van der Ham AC, Kort WJ, Weijma IM, Jeekel H: Transient protection of incomplete colonic anastomoses with fibrin sealant: an experimental study in the rat. J Surg Res 1993;55:256-260.

45 van der Ham AC, Kort WJ: Fibrin sealing of irradiated bowel anastomoses. Dis Colon Rectum 1993;36:614.

46 Volpe M, Costi U, Gianferro A, Albano BR, Marcone P, Sbordoni L: Use of the omental mesh graft in protecting intestinal anastomoses. Experimental research (in Italian). Minerva Chir 1991;46:41-44.

47 Pommergaard HC, Achiam MP, Rosenberg J: External coating of colonic anastomoses: a systematic review. Int J Colorectal Dis 2012;27:1247-1258.

-48 Vakalopoulos KA, Daams F, Wu Z, Timmermans L, Jeekel JJ, Kleinrensink GJ, van der Ham A, Lange JF: Tissue adhesives in gastrointestinal anastomosis: a systematic review. J Surg Res 2013;180:290-300.

49 FDA:Tisseel.http://www.fda.gov/biologicsbloodvaccines/bloodbloodproducts/approvedproducts/licensed productsblas/fractionatedplasmaproducts/ucm089262.htm (accessed June 24, 2014).

50 European Medicines Agency: Fibrinogen-containing solutions for sealant authorised by spray application. http://www.ema.europa.eu/ema/index.jsp?curl=pages/medicines/human/referrals/Fibrinogen-containing_solutions_for_sealant_authorised_for_administration_by_spray_application/human_referral_000332. jsp\&mid=WC0b01ac05805c516f (accessed June 24, 2014).

51 European Medicines Agency: TachoSil. http://www.ema.europa.eu/ema/index.jsp?curl=pages/medicines/ human/medicines/000505/human_med_001072.jsp\&mid=WC0b01ac058001d124 (accessed June 24, 2014).

-52 Liberati A, Altman DG, Tetzlaff J, Mulrow C, Gotzsche PC, Ioannidis JP, Clarke M, Devereaux PJ, Kleijnen J, Moher D: The PRISMA statement for reporting systematic reviews and meta-analyses of studies that evaluate health care interventions: explanation and elaboration. J Clin Epidemiol 2009;62:e1-e34.

-53 Moher D, Liberati A, Tetzlaff J, Altman DG: Preferred reporting items for systematic reviews and meta-analyses: the PRISMA statement. Int J Surg 2010;8:336-341.

54 Giuratrabocchetta S, Rinaldi M, Cuccia F, Lemma M, Piscitelli D, Polidoro P, Altomare DF: Protection of intestinal anastomosis with biological glues: an experimental randomized controlled trial. Tech Coloproctol 2011; 15:153-158.

55 Senol M, Altintas MM, Cevik A, Altuntas YE, Barisik NO, Bildik N, Oncel M: The effect of fibrin glue on the intensity of colonic anastomosis in the presence and absence of peritonitis: an experimental randomized controlled trial on rats. ISRN Surg 2013;2013:521413.

-56 Subhas G, Bhullar JS, Cook J, Shah A, Silberberg B, Andrus L, Decker M, Mittal VK: Topical gentamicin does not provide any additional anastomotic strength when combined with fibrin glue. Am J Surg 2011;201:339-343.

57 Pantelis D, Beissel A, Kahl P, Wehner S, Vilz TO, Kalff JC: The effect of sealing with a fixed combination of collagen matrix-bound coagulation factors on the healing of colonic anastomoses in experimental high-risk mice models. Langenbecks Arch Surg 2010;395:1039-1048.

58 Wang P, Wang J, Zhang W, Li Y, Li J: Effect of the combination of fibrin glue and growth hormone on intestinal anastomoses in a pig model of traumatic shock associated with peritonitis. World J Surg 2009;33:567-576.

59 Li Y, Bao Y, Jiang T, Tan L, Gao Y, Li J: Effect of the combination of fibrin glue and growth hormone on incomplete intestinal anastomoses in a rat model of intra-abdominal sepsis. J Surg Res 2006;131:111-117.

60 Saclarides TJ, Woodard DO, Bapna M, Economou SG: Fibrin glue improves the healing of irradiated bowel anastomoses. Dis Colon Rectum 1992;35:249-252.

-61 Yilmaz HG, Odabasi M, Buyukbayram H, Bac B: Effectiveness of fibrin tissue adhesive for colocolic anastomosis reliability (in Turkish). Ulus Travma Derg 2001;7:87-90.

62 van der Vijver RJ, van Laarhoven CJ, de Man BM, Lomme RM, Hendriks T: The effect of fibrin glue on the early healing phase of intestinal anastomoses in the rat. Int J Colorectal Dis 2012;27:1101-1107.

63 Akgun A, Kuru S, Uraldi C, Tekin O, Karip B, Tug T, Ongoren AU: Early effects of fibrin sealant on colonic anastomosis in rats: an experimental and case-control study. Tech Coloproctol 2006;10:208-214.

64 Ozel SK, Kazez A, Akpolat N: Does a fibrin-collagen patch support early anastomotic healing in the colon? An experimental study. Tech Coloproctol 2006;10:233-236.

65 Van der Ham AC, Kort WJ, Weijma IM, Jeekel H: Transient protection of incomplete colonic anastomoses with fibrin sealant: an experimental study in the rat. J Surg Res 1993;55:256-260. 
66 Van der Ham AC, Kort WJ, Weijma IM, van den Ingh HF, Jeekel H: Effect of fibrin sealant on the integrity of colonic anastomoses in rats with faecal peritonitis. Eur J Surg 1993;159:425-432.

-67 Van der Ham AC, Kort WJ, Weijma IM, van den Ingh HF, Jeekel H: Healing of ischemic colonic anastomosis: fibrin sealant does not improve wound healing. Dis Colon Rectum 1992;35:884-891.

68 Van der Ham AC, Kort WJ, Weijma IM, van den Ingh HF, Jeekel H: Effect of antibiotics in fibrin sealant on healing colonic anastomoses in the rat. Br J Surg 1992;79:525-528.

69 Van der Ham AC, Kort WJ, Weijma IM, van den Ingh HF, Jeekel J: Effect of fibrin sealant on the healing colonic anastomosis in the rat. Br J Surg 1991;78:49-53.

70 Ayhan B, Erikoglu M, Tavli SS, Toy H: A comparison of the application of fibrin glue and adhesive film for repair of anastomotic leaks in the rat. Clin Invest Med 2012;35:E216-E222.

71 Chmelnik M, Lasch L, Weih S, Wink E, Romero P, Holland-Cunz S: Anastomotic sealing with a fibrin-coated collagen patch in small-diameter bowel. Langenbecks Arch Surg 2011;396:685-691.

72 Schreinemacher MH, Bloemen JG, van der Heijden SJ, Gijbels MJ, Dejong CH, Bouvy ND: Collagen fleeces do not improve colonic anastomotic strength but increase bowel obstructions in an experimental rat model. Int J Colorectal Dis 2011;26:729-735.

73 Nordentoft T, Romer J, Sorensen M: Sealing of gastrointestinal anastomoses with a fibrin glue-coated collagen patch: a safety study. J Invest Surg 2007;20:363-369.

74 Li Y, Bao Y, Jiang T, Tan L, Liu F, Li J: Combination of fibrin glue with growth hormone augments healing of incomplete intestinal anastomoses in a rat model of intra-abdominal sepsis: a dynamic study. J Invest Surg 2007;20:301-306.

75 Kanellos D, Blouhos K, Pramateftakis MG, Kanellos I, Demetriades H, Sakkas L, Betsis D: Effect of 5-fluorouracil plus interferon on the integrity of colonic anastomoses covering with fibrin glue. World J Surg 2007;31:186191.

-76 Kanellos I, Christoforidis E, Kanellos D, Pramateftakis MG, Sakkas L, Betsis D: The healing of colon anastomosis covered with fibrin glue after early postoperative intraperitoneal chemotherapy. Tech Coloproctol 2006;10: 115-120.

77 Kanellos I, Mantzoros I, Demetriades H, Kalfadis S, Kelpis T, Sakkas L, Betsis D: Healing of colon anastomoses covered with fibrin glue after immediate postoperative intraperitoneal administration of 5-fluorouracil. Dis Colon Rectum 2004;47:510-515.

78 Kanellos I, Mantzoros I, Goulimaris I, Zacharakis E, Zavitsanakis A, Betsis D: Effects of the use of fibrin glue around the colonic anastomosis of the rat. Tech Coloproctol 2003;7:82-84.

-79 Karahasanoglu T, Alcicek S, Altunkaya E, Sahinler I, Goksel S, Sirin F, Ozbal A: Effect of fibrin glue on irradiated colonic anastomoses. Dis Colon Rectum 1997;40:1240-1243.

-80 Verhage RJ, Ruiz A, Verheem A, Goldschmeding R, Borel Rinkes IH, van HR: Fibrin-thrombin coated sealant increases strength of esophagogastric anastomoses in a rat model. J Surg Res 2012;176:e57-e63.

-81 Yurtcu M, Arbag H, Toy H, Eryilmaz MA, Caglayan 0, Abasiyanik A: The healing effects of tissue glues and healing agent locally applied on esophageal anastomoses. Int J Pediatr Otorhinolaryngol 2010;74:43-46.

82 Rotstein OD, Pruett TL, Simmons RL: Fibrin in peritonitis. V. Fibrin inhibits phagocytic killing of Escherichia coli by human polymorphonuclear leukocytes. Ann Surg 1986;203:413-419.

83 Ciano PS, Colvin RB, Dvorak AM, McDonagh J, Dvorak HF: Macrophage migration in fibrin gel matrices. Lab Invest 1986;54:62-70.

84 Edwards R, Harding KG: Bacteria and wound healing. Curr Opin Infect Dis 2004;17:91-96.

85 Upadhyaya VD, Gopal SC, Gangopadhyaya AN, Gupta DK, Sharma S, Upadyaya A, Kumar V, Pandey A: Role of fibrin glue as a sealant to esophageal anastomosis in cases of congenital esophageal atresia with tracheoesophageal fistula. World J Surg 2007;31:2412-2415.

$>86$ Liu CD, Glantz GJ, Livingston EH: Fibrin glue as a sealant for high-risk anastomosis in surgery for morbid obesity. Obes Surg 2003;13:45-48.

87 Silecchia G, Boru CE, Mouiel J, Rossi M, Anselmino M, Morino M, Toppino M, Gaspari A, Gentileschi P, Tacchino $\mathrm{R}$, Basso N: The use of fibrin sealant to prevent major complications following laparoscopic gastric bypass: results of a multicenter, randomized trial. Surg Endosc 2008;22:2492-2497.

88 Huh JW, Kim HR, Kim YJ: Anastomotic leakage after laparoscopic resection of rectal cancer: the impact of fibrin glue. Am J Surg 2010;199:435-441.

89 Nguyen NT, Nguyen CT, Stevens CM, Steward E, Paya M: The efficacy of fibrin sealant in prevention of anastomotic leak after laparoscopic gastric bypass. J Surg Res 2004;122:218-224.

-90 Bonanomi G, Prince JM, McSteen F, Schauer PR, Hamad GG: Sealing effect of fibrin glue on the healing of gastrointestinal anastomoses: implications for the endoscopic treatment of leaks. Surg Endosc 2004;18:1620-1624.

91 Higgins JPT, Green S: Cochrane Handbook for Systematic Reviews of Interventions Version 5.1.0. The Cochrane Collaboration, 2011. www.cochrane-handbook.org. 2011.

$\$ 92$ Easterbrook PJ, Berlin JA, Gopalan R, Matthews DR: Publication bias in clinical research. Lancet 1991;337: 867-872.

93 Madden JW, Peacock EE Jr: Studies on the biology of collagen during wound healing. I. Rate of collagen synthesis and deposition in cutaneous wounds of the rat. Surgery 1968;64:288-294.

$\$ 94$ Rehn M, Agren MS, Syk I: Collagen levels are normalized after decompression of experimentally obstructed colon. Colorectal Dis 2011;13:e165-e169. 
95 Cronin K, Jackson DS, Dunphy JE: Specific activity of hydroxyproline-tritium in the healing colon. Surg Gynecol Obstet 1968;126:1061-1065.

96 Oxlund H, Christensen H, Seyer-Hansen M, Andreassen TT: Collagen deposition and mechanical strength of colon anastomoses and skin incisional wounds of rats. J Surg Res 1996;66:25-30.

97 Stegemann H, Stalder K: Determination of hydroxyproline. Clin Chim Acta 1967;18:267-273.

98 Phillips JD, Kim CS, Fonkalsrud EW, Zeng H, Dindar H: Effects of chronic corticosteroids and vitamin A on the healing of intestinal anastomoses. Am J Surg 1992;163:71-77.

-99 Ehrlich HP, Tarver H, Hunt TK: Effects of vitamin A and glucocorticoids upon inflammation and collagen synthesis. Ann Surg 1973;177:222-227.

100 Stumpf M, Klinge U, Wilms A, Zabrocki R, Rosch R, Junge K, Krones C, Schumpelick V: Changes of the extracellular matrix as a risk factor for anastomotic leakage after large bowel surgery. Surgery 2005;137:229-234.

101 de Hingh IH, Lomme RM, van GH, Bleichrodt RP, Hendriks T: Changes in gelatinase activity in the gastrointestinal tract after anastomotic construction in the ileum or colon. Dis Colon Rectum 2005;48:2133-2141.

102 de Hingh IH, de Man BM, Lomme RM, van GH, Hendriks T: Colonic anastomotic strength and matrix metalloproteinase activity in an experimental model of bacterial peritonitis. Br J Surg 2003;90:981-988. 